S.W., and S.S.E., the range of Anti-Atlas, rising behind the broad Sous valley, bounded the horizon.

"At our feet, and cutting off from view the course of the river Sous, the mountain mass that here forms the axis of the main chain presented the appearance of a troubled sea of a light ferruginous colour, declining gradually in elevation from $W$. to $E$. At a distance of about eight miles E.S.E. of Djebel Tezah it sinks to an estimated height of little over 7,000 feet, at the head of the main branch of the Oued Nfys, and offers the only apparently easy pass over the main chain which we had yet seen. The rocky sunburnt flanks of the mountains were dotted with trees of dark foliage, doubtless some form of the evergreen oak, up to a height of about 8,000 feet above the sea, for the most part solitary, sometimes in clumps, but nowhere forming a continuous forest. The numerous feeders of the Oued Nfys had cut deep ravines in the flanks of the mountains, and were lost to sight, except twhere gleams of silver light shot upwards from the deeper valleys amid the walnut trees that fringed their banks. Numerous hamlets were seen, some perched upon projecting ridges, some lying in hollows and girdled with a belt of emerald-green crops.

"It was impossible not to speculate on the condition of these primitive mountaineers, who have since the dawn of history preserved their independence. Leo Africanus, speaking of the very district now overlooked by us, which he calls Guzula, says that the people were in his day molested by the predatory Arabs and by 'the lord of Marocco;' but they successfully resisted all encroachments, and no attempt is now made to assert the Sultan's authority among them, or to enforce tribute. Something they have doubtless gained in material, and still more in moral, welfare by stubborn resistance to alien rule; but the prosperity that is sometimes attained by tribes subject to the semi-feudal rule of chiefs, and among whom intestine feuds are rooted in immemorial tradition, is usually shortlived.

"Our hope of getting further knowledge as to the eastern extremity of the Sous valley, and the orographic relations between the Atlas and Anti-Atlas ranges was not to be satisfied. Djebel Tezah, as we found, stands some way north of the axis of the chain, while the great mass that rose over against us between E.N.E. and E.S.E., extending to the head of the Aït Mesan valley, sends out massive buttresses to the south, and by these our view of Anti-Atlas was cut off to the S.E. On one of these western projecting buttresses we could distinguish a large village belonging to the district of Tifinout, and standing at an elevation of nearly 7,000 feet. Turning our eyes to the north of true east, many of the higher summits of the chain were seen rising above the intervening ranges, the most distant probably belonging to the Glaoui group, east of Tasseremout. Once more we came to the conclusion that throughout the portion of the Great Atlas chain visible from the city of Marocco, between the easternmost feeders of the Oued Tensift and those of the Oued Nfys, there are no prominent peaks notably surpassing the average level. Many of them must surpass the limit of 13,000 feet above the sea, but it is not likely that any one attains the level of 13,500 feet. The last object that attracted our attention in the panorama, in a direction about east by north, was an isolated mass, forming a bold promontory on the northern side of the chain, of which a rough outline is here given.

"When the engrossing inlerest of the distant view bad so far subsided as to let us pay attention to nearer objects, we were struck by the unexpected appearance of considerable remains of dwellings on a platform of level ground, only a few feet below the actual summit of the mountain. About a dozen rude stone dwellings, all in a ruinous con-

$x$ This is apparently the pass spoken of by Leo Africanus as leading from meat Imizmizi (Amsmiz?) to the region of Guzula (the northern branch of the Sous valley). He says it is called Burris, that word meaning downy, because snow frequently falls there.-See "Ramusio," vol. i. p. 17, B. dition, with chambers sunk a couple of feet below the level of the ground, and the roofs fallen in, had at some former period been here erected ; but we saw no traces of recent occupation. It seemed most probable that they were intended as shelter for herdsmen, who had driven their flocks in summer to this lofty station.

"As we lingered on the topmost point of the mountain, the intense silence of the scene was broken by the distant scream of a large grey eagle that soared over our heads, and then sailed away southward over the Sous valley, making the deep stillness still more sensible than before."

No wonder that after the excitement of such a day, which only ended when their quarters were reached at half-past eight at night, the travellers let their collections rest in the collecting boxes and portfolios for the night, and after supper fell themselves to sleep.

Wars among the native tribes at last drove our authors to the necessity of returning to Mogador, passing through the wonderfully singular defile of Ain Tarsil, which is like a trench some thirty to fifty feet wide and the same deep, running for a length of nearly three miles. Four. days were spent on the occasion of the second visit to Mogador, and Sir Joseph Hooker reached London with his collections in safety on June $2 \mathrm{I}$.

Having in this notice exceeded the space at our disposal, we can only quite incidentally allude to the very valuable appendices to this volume, which treat of the geography, geology, and flora of the districts visited.

Since we some years ago closed the pages of "Palgrave's Personal Narrative of a Year's Journey through Central and Eastern Arabia," we have not perused a more delightful or instructive book of travels than this account of a tour in Marocco. From the well-known acquirements and great experience of the authors we expected much, and we have not been disappointed. The journal is, without doubt, especially pleasant reading to a botanist, but the geographer will find in it much to interest him, the politician will find in the description of the state of things now existing in such a country material for some serious thought, while the literary taste of every reader will be gratified by the excellent manner in which the narrative is written.

\section{REORGANISATION OF THE AMERICAN SURVEYS}

A LL well-wishers of the progress of geographical and geological research will welcome the intelligence that in the official estimates for the present year just presented to Congress the complete remodelling of the surveys carried on by the United States has been recommended to be immediately undertaken. The Report recently made by the National Academy of Sciences, to which attention was lately called in these pages (NATURE, vol. xix. p. 213), seems to have been adopted simpliciter. The Engineer Department is henceforth to be charged with no surveys save such as may be required for military purposes. The surveys of mensuration are to be placed under one organisation, and a new Geological Survey of the United States is to be instituted. Of course the changes are at present only recommended for adoption by the Committee on Appropriations, and there may be a struggle over some of the proposals. We hear indeed that the Engineers are leaving no point in their defence unguarded and are preparing for what is called a "heavy fight." For their own sakes as well as for the cause of scientific progress we cannot wish them success.

They object to the constitution of the Academy's Committee on the ground that only one of the members of it knows anything practically of surveying. And this objection will no doubt be urged with force and persistence in the debates in Congress. But surely they can hardly expect to throw dust in the eyes of the legislature by such a flimsy argument. The Committee, as we formerly pointed 
out, was a thoroughly competent one. They might as well insist that nobody is competent to pass a judgment on poetry unless he has written an epic, or to criticise fine art if he has not painted a picture, or modelled a statue. The Bureau of Engineers has done such admirable work and deserves such thorough respect, that its best friends can only hope that it will not embitter a fruitless struggle against the inevitable. We have no fear that its scientific prestige will in the least be diminished by the projected revolution. The nature of the change will be best understood from the following extracts from the Bill of the Committee on Appropriations, which has been read twice and "committed to a committee of the whole House on the state of the Union and ordered to be printed ":-

"For the salary of the Superintendent of the Coast and Interior Survey, 6,000 dollars: Provided, That the present coast and geodetic survey, with supervisory and appellate powers over the same authorised by law, is hereby transferred from the Treasury Department to the Department of the Interior, and shall hereafter be known as the Coast and Interior Survey, and shall have charge of all surveys relating to questions of position and mensuration of the coast and interior, except the special survey necessary for geological purposes, the survey of the northern and north-western lakes now under the direction of the War Department, and local surveys required for the improvement of rivers and harbours and surveys necessary for military purposes immediately connected with the operations of the army, in accordance with the plan reported to Congress by the National Academy of Sciences, under the Act of June 20, 1878, entitled 'An Act making Appropriations for Sundry Civil Expenses of the Government for the Fiscal Year ending June 30, 1879, and for other purposes:' And provided further, That the offices of surveyors-general are hereby abolished, to take effect on June 30,1879 ; and the compensation of said surveyors-general, and all employees under them, shall cease on that day; and the duties pertaining to the offices of surveyors-general shall thereafter be performed by the Superintendent of the Coast and Interior Survey; and the parcelling surveys of the public lands shall hereafter be made by employees of the Coast and Interior Survey : And provided further, That the rectangular method with township and sectional units shall be retained wherever it can be appropriately and economically applied, but all surveying by contract shall be prohibited; and the Superintendent of the Coast and Interior Survey is hereby authorised to adopt such additional surveying methods as he may deem most economic and accurate; but the surveys of mineral claims shall be made by deputy surveyors, as now provided by law. And such of the archives and records now in the offices of the surveyors-general as may not be required for the office of the Superintendent of the Coast and Interior Survey shall be turned over to the governors of the several States and Territories, upon the same terms and conditions and in the same manner that the archives have heretofore been delivered to the State authorities in States where the public surveys have been completed and the offices of the surveyors-general closed: And provided further, That the Secretary of the Interior shall direct the archives and records of the surveyor-general's office of any State or Territory to be kept in the place where they are now located, if thereby the interests of the people of said State or Territory will be best subserved, such archives and records to be placed under the charge of an employee of the Coast and Interior Survey: And provided further, That hereafter surveys of public lands shall, at the discretion of the Secretary of the Interior, be made under the deposit system, on petition of not less than five persons for the survey of a township; the sum of money to be deposited for the survey of the township shall equal the cost of the survey at the present rates allowed for the several classifications of the land to be surveyed, including: such sum as shall be estimated for office-work: Provided, That the excess of any deposit over and above the aforesaid cost shall be returned to the depositor; and all moneys so deposited and actually required for said survey and office-work, for the amount of land for the survey of which the petition is filed, shall be applicable, either in the hands of the depositor or his assignee, to pay for lands to which the said depositor or others may be entitled under the law. It shall be the duty of the. Commissioner of the Land Office to make all needful rules and regulations necessary for carrying into effect the detail of this law, so far as relates to the new conditions established by it in reference to the public lands.

"For the salary of the Director of the Geological Survey, which office is hereby created, who shall be appointed by the President by and with the advice and consent of the Senate, 6,000 dollars: Provided, That this officer shall have the direction of the geological survey, and the classification of the public lands and examination of the geological structure, mineral resources, and products of the national domain, in accordance with the plan reported to Congress by the National Academy of Sciences under the act of June 20, 1878 , entitled 'An Act making Appropriations for Sundry Civil Expenses of the Government for the Fiscal Year ending June 30,1879 , and for other purposes ;' and that the director and members of the geological survey shall have no personal or private interests in the lands or mineral wealth of the region under survey, and shall execute no surveys or examinations for private parties or corporations; and the Geological and Geographical Survey of the Territories, and the Geographical and Geological Survey of the Rocky Mountain Region, under the Department of the Interior, and the Geographical Surveys west of the rooth imeridian, under the War Department, are hereby discontinued, to take effect on June 30,1879 ; and all collections of rocks, minerals, soils, fossils, and objects of natural history, archæology, and ethnology, made by the Coast and Interior Survey, the Geological Survey, or by any other parties for the Government of the United States, when no longer needed for investigations in progress, shall be deposited in the National Museum.

"That all laws, parts of laws, and all departmental regulations relating or having reference to the coast and geodetic survey now in force and effect are hereby continued in force and effect, and made applicable to the Coast and Interior Survey until changed by competent authority.

"For the expense of a commission on the codification of existing laws relating to the survey and disposition of the public domain, and for other purposes, 20,000 dollars: Provided, That the commission shall consist of the Commissioner of the General Land Office, the Superintendent of the Coast and Interior Survey, the Director of the United States Geological Survey, and three civilians, to be appointed by the President, who shall receive a per diem compensation of Io dollars for each day while actually engaged, and their travelling expenses; und neither the Commissioner of the General Land Office, the Superintendent of the Coast and Interior Survey, nor the Director of the United States Geological Survey, shall receive other compensation for their services upon said commission than their salaries, respectively, except their travelling expenses, while engaged on said duties; and it shall be the duty of this commission to report to Congress within one year from the time of its organisation : first, a codification of the present laws relating to the survey and disposition of the public domain; second, a system and standard of classification of public lands as arable, irrigable, timber, pasturage, swamp, coal, mineral lands, and such other classes as may be deemed proper, having due regard to humidity of climate, supply of water for irrigation, and other physical characteristics; 
third, a system of land-parcelling surveys adapted to the economic uses of the several classes of lands; and, fourth, such recommendations as they may deem wise in relation to the best method of disposing of the public lands of the western portion of the United States to actual settlers.

"The publications of the Coast and Interior Survey shall consist of the annual report of operations, such geographic and topographic maps, and geodetic and coast charts, and such discussions and treatises connected therewith, as the superintendent shall deem of value. The publications of the Geological Survey shall consist of the annual report of operations, geological and economic maps illustrating the resources and classification of the lands, and reports upon general and economic geology and palæontology. The annual report of operations of the Coast and Interior Survey and of the Geological Survey shall accompany the annual report of the Secretary of the Interior. All special memoirs and reports of both surveys shall be issued in uniform quarto series. The style and scale of the cartographic publications shall be determined by the head of each organisation, so as to express the scientific results in the most effective manner. Three thousand copies of each shall be published for scientific exchanges by the heads of the surveys and for sale at the price of publication; and all literary and cartographic materials received by the heads of the surveys in exchange shall be the property of the United States, and form a part of the libraries of the two organisations; and the money resulting from the sale of such publications shall be paid into the Treasury of the United States."

\section{HEINRICH GEISSLER}

A YEAR since we were called upon to chronicle the death of Ruhmkorff, whose name is so closely identified with the history of electricity. In recording the death of Dr. Heinrich Geissler at Bonn, January 24, we regret the loss to the world of science of an equally important and esteemed worker. He was born in the village of Igelshieb, in Central Germany, in the year 1814. At an early age he mastered the art of glass-blowing-an industry which has long flourished in his native duchy of Sachsen-Meiningen-and for a number of years he led the life of a German Handwerksbursch, rambling from one place to another, accepting employment wherever it was offered. The German University towns offered to him the chief attraction, the preparation of the articles requisite for scientific research having for him a peculiar fascination; and his wandering life finally ended in a permanent settlement at Bonn. Here he developed rapidly. In the treatment of glass before the blowpipe he attained a degree of perfection hitherto unknown, and in his day unsurpassed. Despite the disadvantages of his early life, and the demands of his occupation, he succeeded in making rapid acquisitions in various departments of the natural sciences; and favoured by association with numerous leading celebrities, in physics and chemistry, he soon attained a remarkably comprehensive and intimate familiarity with scientific facts and principles. The union of this knowledge with his constructive ability and manualaccomplishments was productive of the happiest results, and the past thirty years have witnessed a constant succession of novel and ingenious devicesfor the furtherance of scientific discovery, issuing from his atelier. Not only was he able to accomplish the practical realisation of the designs submitted to him, but in a multitude of cases, when simply the end in view was proposed to him, Geissler planned and produced apparatus of the most delicate construction, and exact precision, involving a mastery of physical laws to be expected only in one who had devoted his life to the solution of scientific problems. The impuise thus given by him to the march of original investigation is not easy to measure, for his name is rarely associated with the numerous discoveries where his fruitful ideas have contributed in a greater or less degree to the successful result. One of his earliest direct investigations was in companionship with the distinguished physicist, Plücker, in 1852. By means of a delicate apparatus, in which the expansion of the glass was exactly compensated by the introduction of mercury, they made a series of accurate observations on the expansion of water, and established the maximum of density at $3.8^{\circ}$. With an equal degree of accuracy the coefficient of expansion for $I^{\circ}$ of ice between $-24^{\circ}$ and $-7^{\circ}$ was established at o'oor 585 , and the coefficient of expansion for water when freezing at $0^{\circ}$, was ascertained to be 0.09195 . In 1869, Geissler, in company with Vogelsang, demonstrated in an ingenious manner the presence of liquid carbonic acid in the cavities of topaz and quartz. The minerals were decomposed by means of a galvanic current, the resultant gases were collected in a vacuum, and the presence of $\mathrm{CO}_{2}$ was shown by the electric arc. They succeeded, likewise, in producing a precipitation in lime-water, and established beyond doubt the character of the liquid present. Shortly after Geissler succeeded in changing ordinary phosphorus into the amorphous state by the action of the electric current.

The apparatus with which Geissler's name is most popularly associated consists in the famous tubes arranged for the exhibition and study of the phenomena accompanying the electric discharge in various gases and vapours. Their ingenious disposition has contributed much to the progress of research on the nature of the electric light and the condition of matter in the gaseous state. Scarcely less important are his inventions of the vaporimeter, the mercury air-pump, as well as the balances, normal thermometer, and normal areometer, and other instruments of precision devised by him, which have rendered such incalculable service to those engaged in exact research. A few years since the University of Bonn rendered a fitting tribute to the varied merits of Geissler by bestowing on him the honorary title of Doctor of Philosophy.

The career of Geissler was in many respects similar to that of Rubmkorff. Both advanced from the lowest ranks of life to positions of honour in the scientific world, both gave, in a quiet and almost unrecognised manner, an important impulse to the cause of physical investigation, and both have left their names as "household words" in the nomenclature of the science to which they were so faithfully devoted.

T. H. N.

\section{GEOGRAPHICAL NOTES}

LIEUT. WEYPRECHT informs us, with reference to his proposed scientific expedition to Novaya Zemlya that the statements which have appeared are very inaccurate, nothing having as yet been decided. He and Count Wilczek certainly intend to go there and make one year's thorough scientific observation in some place on the northern coast; special attention will be given to cosmical physics. They would prefer, however, if in other places of the Arctic and Antarctic regions, others would make observations simultaneous with them. Before the war broke out they had the best hopes of seeing their proposals nearly everywhere accepted, but the disturbed state of Europe during the last two years has prevented them from taking further steps. In April the International Meteorological Congress, which was to have met in 1877 , will meet in Rome. One of the questions to be decided there will be, in what manner the Congress can contribute to the realisation of the proposals of Count Wilczek and Lieut. Weyprecht. On the decision come to at that meeting will theirs mainly depend. The programme which it is intended to carry out will be found described in NATURE, rol. xvii. p. 29. 